\title{
Impacts of Coronavirus on Farm, Pet, and Zoo Animals
}

\author{
Sachin Subedi ${ }^{1}$, Sulove Koirala ${ }^{1}$, Lilong Chai ${ }^{2 *}$
}

1. Faculty of Animal Science, Veterinary Science and Fisheries, Agriculture \& Forestry

University, Chitwan, Nepal.

Email: S. Subedi: sachinsubedi59@gmail.com; S. Koirala: sulovekoirala@gmail.com

2. Department of Poultry Science, University of Georgia, Athens, GA, USA.

Email: 1chai@uga.edu

* Author to whom correspondence should be addressed.

Abstract: Coronaviruses are positive sense RNA virus belonging to the Coronaviridae family, which are further subdivided into four genera: Alpha, Beta, Gamma, and Delta Coronaviruses. Infectious bronchitis virus and SARS-CoV belong to Beta Coronaviridae family. Infectious bronchitis virus causes respiratory and nephritic signs that includes tracheal rales, urate crystals, lethargy and nasal discharge. In livestock and pets, the Coronavirus infection causes mostly gastrointestinal lesions, which may be prevented through vaccination and biosecurity. Recent infections of SARS-CoV-2 (also known as COVID-19) on farm, pet, and zoo animals were summarized in this study. Although the damage of COVID-19 has not been reported in commercial livestock and poultry, the transmission mechanism of COVID-19 among group animals and farms are not still clear. The impact of Coronavirus on animals and potential prevention strategies, such as vaccine development and farm biosecurity measures, were discussed. Before the right vaccine is successfully marketed, biosecurity measures (e.g., conventional disinfection strategies and innovated technologies) may play roles in preventing potential airborne transmission.

Keywords: Coronavirus, SARS-CoV-2, animals; nephritic, vaccination, biosecurity measures 


\section{Introduction}

Coronaviruses are positive sense RNA virus named for solar corona like appearance (meaning crown) with helical nucleocapsid measuring 80 to $160 \mathrm{~nm}$. It consists of glycoproteins on the surface of envelope appearing as club shaped projections that measure $20 \mathrm{~nm}$ in length and 5-11 $\mathrm{nm}$ inn width [1]. Coronaviruses (CoVs) are the largest group of viruses belonging to the Nidovirales order, which includes Coronaviridae, Arteriviridae, Mesoniviridae, and Roniviridae families. The Coronavirinae comprise one of two subfamilies in the Coronaviridae family, with the other being the Torovirinae [2]. The Coronavirinae are further subdivided into four genera: the alpha, beta, gamma, and delta coronaviruses. The viruses were initially sorted into these genera based on serology but are now divided by phylogenetic clustering [3].

Table 1. Coronavirus Groups, Target Tissues, and Diseases [4,5]

\begin{tabular}{|c|c|c|c|}
\hline Genetic Group & Virus & Host & Infection site \\
\hline Alpha & HCoV-229E & Human & Upper respiratory tract \\
\hline Alpha & $\begin{array}{l}\text { TGEV } \\
\text { PRCV } \\
\text { PEDV }\end{array}$ & Pig & $\begin{array}{l}\text { Upper respiratory tract, Small intestine, } \\
\text { Upper Respiratory tract, lungs, Viremia }\end{array}$ \\
\hline Alpha & $\begin{array}{l}\text { F1PV } \\
\text { FCoV }\end{array}$ & Cat & $\begin{array}{l}\text { Upper Respiratory tract, enteric and systemic } \\
\text { signs } \\
\text { Small intestine }\end{array}$ \\
\hline Alpha & $\mathrm{CCoV}$ & Dog & Small Intestine \\
\hline Alpha & $\mathrm{RaCoV}$ & Rabbit & Systemic signs \\
\hline Beta & $\mathrm{HCoV}-\mathrm{OC} 43$ & Human & Upper respiratory tract \\
\hline Beta & NUN & Mouse & Hepatitis, CNS, systemic signs \\
\hline Beta & RcoV & Rat & Salivary glands, eye \\
\hline Beta & $\mathrm{BEV}$ & Pig & Respiratory tract \\
\hline
\end{tabular}




\begin{tabular}{|c|c|c|c|}
\hline Beta & BcoV & Cattle & Lungs, colon \\
\hline Beta & SARS-CoV & Human & Upper respiratory tract, lungs, viremia, kidney \\
\hline Beta & SARS-CoV-2 & Human & Lower respiratory tract \\
\hline Beta & Civet cat CoV & $\begin{array}{c}\text { Himalayan palm } \\
\text { civet }\end{array}$ & Subclinical? \\
\hline Beta & Raccoon dog CoV & Raccoon dog & Upper respiratory tract, lungs, \\
\hline Gamma & IBV & Chicken & Small intestine \\
\hline Gamma & TCoV (TECoV) & Turkey & Gastrointestinal tract \\
\hline Delta & HKU12 & Mammals, Birds, & Pigs \\
& HKU13 & & \\
\hline
\end{tabular}

Note: $?=$ Unknown, CNS $=$ Central Nervous System.

\section{Coronaviruses in Farm Animals and Pets}

Infectious bronchitis is an acute, highly contagious disease of poultry characterized by tracheal rales, coughing and sneezing [6]. It is caused by IBV virus, a member of Coronaviridae family which is single stranded RNA virus. Chicken is naturally infected though susceptibility varies among breeds and strain of chicken [6]. It is horizontally transmitted via aerosol route. The virus may also be transmitted through contaminated feed and equipment [7]. Birds of all ages are susceptible, but chicks of 1-4 weeks of age are most severely affected. After invasion virus localizes in the respiratory system, following which a viremia occurs and the virus is distributed in the body and affect reproductive and urinary system and replicates up to 1-8 days post infection. Incubation period is about $18-30$ hours. Symptoms includes respiratory and nephritic form. Common clinical signs are tracheal rales, sneezing, nasal discharge, depression, ruffled feathers, wet droppings and urolithiasis [8]. Post mortem lesions include cloudy air sacs, catarrhal tracheal exudates [9]. Pneumonia may also be seen. Kidneys are pale swollen with tubules and ureters are often distended with urates. Diagnosis can be done according to clinical signs, PM lesions, virus isolation in chick embryo serological tests [10]. Treatment is non-specific and antimicrobial therapy is recommended. Prevention is done by vaccination of birds with strict isolation procedure for affected birds and disinfection of the poultry house [11]. In general, it is recommended to allow two weeks between two live IB 
vaccinations and obtain a good booster effect of the inactivated vaccines, preferably 4-6 weeks should elapse between the last live vaccination and the application of the inactivated vaccine [12].

It is highly contagious disease of domestic animals, specially of canine and bovine of young age group, characterized by gastroenteritis [13]. Canine population is the main host of this viral infection causing Canine Corona Virus (CCV) disease [14]. Transmissible Gastroenteritis (TGE) causes profuse diarrhea and vomiting in pigs, it results in serious atrophy of intestinal villi [15]. Transmission is mainly through fecal contamination and vomitus [16]. The virus invades the small intestine, damage the intestinal villi resulting in profuse diarrhea [17]. Clinical signs include depression, anorexia, lethargy, vomiting, prolonged diarrhea (7-10) days with yellow orange colored fecal materials with occasional mucus or blood. Cat may also show vomiting and diarrhea accompanied by fever [18]. The intestinal villi are atrophied and desquamated [19]. Serological tests like AGID, ELISA and PCR can also be done [20]. This disease is often confused weigh canine parvo virus due to similar clinical signs [21]. Symptomatic treatment to control diarrhea along with fluid therapy is recommended [21]. Vaccination is most effective method for prevention of this disease [20].

\section{Animals with SARS-COV-2 (COVID-19)}

It is suggested that SARS CoV may also have a broad host range besides humans. Genetically similar CoVs were isolated from civet cats and raccoon dogs [22]. In experimental studies, the SARS CoV infected and caused disease in macaques and ferrets and cats' sub clinically [4]. COVID-19 is caused by SARS-CoV-2 (Severe acute respiratory syndrome coronavirus 2). This disease was firstly reported in Wuhan, China in December 2019 [23]. It was thought to be originated from bats though the intermediate animal sources of virus are still unknown [24]. SARS-CoV-2 replicates poorly in canine, swine and poultry but ferrets and cats are permissive to infection [25]. Bats, civets, and camels have been the recent animal carriers of human $\mathrm{CoV}$ infections [26]. Bats and pangolins are considered to be the probable sources of origin of SARS-CoV2 [27,28]. Cats has been found to be the asymptomatic carrier of COVID-19 [29]. 
Pets cats in Hongkong, Tigers in Zoo and Mink on farms in Netherlands were reported cases of coronaviruses with several species, including pet dogs and cats, captive lions and tigers are susceptible to the virus [30]. A veterinary virologist at Kansas State University, indicated that farmed mink, mink, weasels, badgers, martens and wolverines could be susceptible [30]. Pigs, ducks and chickens are found to be non-susceptible after experiments, but there have been no studies of other livestock animals, such as cows, sheep and horses [31]. There have been only two reported cases of animals both mink passing the virus SARS-CoV-2 to people, which is proved after genomic analysis from mink and people [32].

Table 2 shows the summarized information regarding impacts of COVID-19 on pets and farm animals.

\begin{tabular}{|c|c|c|c|c|}
\hline $\begin{array}{c}\text { Farm } \\
\text { Animals/Pets/O } \\
\text { thers }\end{array}$ & Animal type & Country/Remarks & Date & Source \\
\hline Pets & Dogs & Hong Kong, China & Feb, 2020 & [33] \\
\hline Farm Animals & Mink & Netherlands & April, 2020 & {$[34]$} \\
\hline Pets & Cats & Belgium & March, 2020 & {$[35]$} \\
\hline Pets & Cats & Hong Kong, China & March, 2020 & {$[36]$} \\
\hline Others & Cats \& Ferrets & China & March, 2020 & {$[31]$} \\
\hline Pets & Dogs & Hong Kong, China & March, 2020 & [37] \\
\hline Others & Tiger & India & April, 2020 & {$[38]$} \\
\hline Pets & Cats & USA & April, 2020 & [39] \\
\hline Others & Tiger, Lion & USA & April, 2020 & [40] \\
\hline Pets & Cats & Netherlands & May, 2020 & {$[41]$} \\
\hline Pets & Cats & $\begin{array}{c}\text { Experimental/ } \\
\text { Japan }\end{array}$ & May, 2020 & [42] \\
\hline Pets & Cats & Germany & May, 2020 & {$[43]$} \\
\hline Pets & Cats & France & May, 2020 & {$[44]$} \\
\hline Farm animals & Mink & Netherlands & May, 2020 & [32] \\
\hline
\end{tabular}

\section{Coronavirus Prevention on Animal Farms}

COVID-19 has yet caused disaster infection in commercial livestock and poultry as what the Highly Pathogenic Avian Influenza (HPAI) or African Swine Fever (ASF) has led. But the transmission mechanism 
of COVID-19 among group animals and farms are not well studied yet. Vaccination is the most efficient for stopping the spread of COVID-19, but the commercial canine coronavirus vaccine that is available will not provide cross protection as it is effective for enteric coronavirus only [45]. Before the right vaccine is successfully developed and marketed, conventional and emerging measures of on-farm biosecurity may help prevent transmission of COVID-19 among farm animals. Conventional farm biosecurity measures include vehicles disinfection with liquid spraying, ultraviolet light, and shower-in and show-out for all farm staff and visitors. Emerging biosecurity measures such as heat treatment and electrostatic air filtration have been tested in the US in recent years. Scientists have developed a heat treatment method (i.e., heat room temperature to $60^{\circ} \mathrm{C}$ over hours) for disinfecting egg transportation tools during outbreak of HPAI in Midwest [46]. Besides, an electrostatic air filtration system was tested for filtering the airborne dust at the inlet of poultry housing ventilation system to prevent potential airborne transmission of HAPI between farms or between animal houses on the same farm [47,48]. Those conventional and innovated biosecurity measures may be considered by producers if there are any outbreak of COVID-19 in farm animals.

\section{Summary}

The primary coronavirus groups, target tissues, and diseases in farm animals and pets are systematically summarized to present the correlation between coronavirus and some other relevant diseases. Being as viral disease, the treatment of the condition is non-specific and antibiotic therapy is done for secondary bacterial infections.

The outbreak/infections of COVID-19 among farm, pet, and zoo animals were summarized in this study. Increasing positive COVID-19 cases have been reported in cats and farm minks. It is necessary to test both the animals and individuals that can be in close contact with each other in order to find out cross transmission and potential infections.

Vaccination of animals is the prophylactic measure for the control and prevention of Coronavirus. However, an efficient vaccine has been yet developed. Prior to the development of a successful vaccine, on-farm 
biosecurity strategies (e.g., conventional disinfection measures and innovative engineering technologies of electrostatic air filtration and heat treatment method) may play a role in preventing the spread of COVID19 between commercial farms or animals.

Author Contributions: S.S. and L.C. came up the research thoughts; S.S., S.K. and L.C. collected the information; S.S., S.K. and L.C wrote the manuscript; All authors have read and agreed to the submission of the manuscript. 


\section{References}

1. Doughri, A.M.; Storz, J.; Hajer, I.; Fernando, H.S. Morphology and morphogenesis of a coronavirus infecting intestinal epithelial cells of newborn calves. Experimental and Molecular Pathology 1976, 25, $355-370$.

2. Taxonomy, V.; Murphy, F.A. Ninth report of the international committee on taxonomy of viruses. Virus Taxonomy. San Diego, CA: Elsevier 2012, 1281-325.

3. Woo, P.C.; Huang, Y.; Lau, S.K.; Yuen, K.-Y. Coronavirus genomics and bioinformatics analysis. viruses 2010, 2, 1804-1820.

4. Saif, L.J. Animal coronaviruses: Lessons for SARS. Learning from SARS: Preparing for the Next Disease Outbreak. The National Academies Press, Washington, DC 2004, 138-149.

5. Wang, W.; Xu, Y.; Gao, R.; Lu, R.; Han, K.; Wu, G.; Tan, W. Detection of SARS-CoV-2 in Different Types of Clinical Specimens. JAMA 2020, 323, 1843-1844, doi:10.1001/jama.2020.3786.

6. Broadfoot, D.I.; Smith Jr, W.M. Effects of infectious bronchitis in laying hens on egg production, percent unsettable eggs and hatchability. Poultry Science 1954, 33, 653-654.

7. Cunningham, C.H. Avian infectious bronchitis. Adv Vet Sci Comp Med 1970, 14, 105-148.

8. Cumming, R.B. STUDIES ON AVIAN INFECTIOUS BRONCHITIS VIRUS: 2. Incidence of the Virus in Broiler and Layer Flocks, by Isolation and Serological Methods. Australian veterinary journal 1969, 45, 309-311.

9. Alexander, D.J.; Gough, R.E.; Pattison, M. A long-term study of the pathogenesis of infection of fowls with three strains of avian infectious bronchitis virus. Research in veterinary science 1978, 24, $228-233$.

10. Crinion, R.A.; Ball, R.A.; Hofstad, M.S. Pathogenesis of oviduct lesions in immature chickens following exposure to infectious bronchitis virus at one day old. Avian Dis. 1971, 15, 32-41.

11. Go, P.C.V.V.E.; Sansthan, A. Emergence of Avian Infectious Bronchitis Virus and its Variants Need Better Diagnosis, Prevention and Control Strategies: A Global Perspective" Kuldeep Dhama," Shambhu Dayal Singh," Rajamani Barathidasan,"PA Desingu,"Sandip Chakraborty. Pakistan Journal of Biological Sciences 2014, 17, 751-767.

12. Jackwood, M.W.; Wit, S. de Infectious Bronchitis. In Diseases of Poultry; John Wiley \& Sons, Ltd, 2019; pp. 167-188 ISBN 978-1-119-37119-9. 
13. Agnihotri, D.; Singh, Y.; Batra, K.; Jain, V.K.; Kumar, A.; Kumar, T.; Maan, S. Molecular Detection Based Epidemiology of Canine Parvovirus and Canine Coronavirus Infection in Diarrheic Dogs in Haryana. Journal of Animal Research 2018, 8, 367-374.

14. Buonavoglia, C.; Decaro, N.; Martella, V.; Elia, G.; Campolo, M.; Desario, C.; Castagnaro, M.; Tempesta, M. Canine coronavirus highly pathogenic for dogs. Emerging infectious diseases 2006, 12, 492.

15. Hooper, B.E.; Haelterman, E.O. Lesions of the Gastrointestinal Tract of Pigs Infected with Transmissible Gastroenteritis. Can J Comp Med 1969, 33, 29-36.

16. Saif, L.J. Coronaviruses of domestic livestock and poultry: interspecies transmission, pathogenesis, and immunity. Nidoviruses 2007, 279-298.

17. Wege, H.; Ter Meulen, V. The biology and pathogenesis of coronaviruses. In Current topics in microbiology and immunology; Springer, 1982; pp. 165-200.

18. de Groot-Mijnes, J.D.; Van Dun, J.M.; Van Der Most, R.G.; De Groot, R.J. Natural history of a recurrent feline coronavirus infection and the role of cellular immunity in survival and disease. Journal of virology 2005, 79, 1036-1044.

19. Pratelli, A.; Tempesta, M.; Roperto, F.P.; Sagazio, P.; Carmichael, L.; Buonavoglia, C. Fatal coronavirus infection in puppies following canine parvovirus $2 \mathrm{~b}$ infection. Journal of Veterinary Diagnostic Investigation 1999, 11, 550-553.

20. Pratelli, A.; Buonavoglia, D.; Martella, V.; Tempesta, M.; Lavazza, A.; Buonavoglia, C. Diagnosis of canine coronavirus infection using nested-PCR. Journal of virological methods 2000, 84, 91-94.

21. Godsall, S.A.; Clegg, S.R.; Stavisky, J.H.; Radford, A.D.; Pinchbeck, G. Epidemiology of canine parvovirus and coronavirus in dogs presented with severe diarrhoea to PDSA PetAid hospitals. Veterinary Record 2010, 167, 196-201.

22. Guan, Y.; Zheng, B.J.; He, Y.Q.; Liu, X.L.; Zhuang, Z.X.; Cheung, C.L.; Luo, S.W.; Li, P.H.; Zhang, L.J.; Guan, Y.J. Isolation and characterization of viruses related to the SARS coronavirus from animals in southern China. Science 2003, 302, 276-278.

23. Andersen, K.G.; Rambaut, A.; Lipkin, W.I.; Holmes, E.C.; Garry, R.F. The proximal origin of SARS-CoV-2. Nature Medicine 2020, 26, 450-452, doi:10.1038/s41591-020-0820-9. 
24. Shereen, M.A.; Khan, S.; Kazmi, A.; Bashir, N.; Siddique, R. COVID-19 infection: Origin, transmission, and characteristics of human coronaviruses. Journal of Advanced Research 2020, 24, 9198, doi:10.1016/j.jare.2020.03.005.

25. Tiwari, R.; Dhama, K.; Sharun, K.; Iqbal Yatoo, Mohd.; Malik, Y.S.; Singh, R.; Michalak, I.; Sah, R.; Bonilla-Aldana, D.K.; Rodriguez-Morales, A.J. COVID-19: animals, veterinary and zoonotic links. Veterinary Quarterly 2020, 40, 169-182, doi:10.1080/01652176.2020.1766725.

26. Cui, J.; Li, F.; Shi, Z.-L. Origin and evolution of pathogenic coronaviruses. Nat Rev Microbiol 2019, 17, 181-192, doi:10.1038/s41579-018-0118-9.

27. Wu, A.; Peng, Y.; Huang, B.; Ding, X.; Wang, X.; Niu, P.; Meng, J.; Zhu, Z.; Zhang, Z.; Wang, J.; et al. Genome Composition and Divergence of the Novel Coronavirus (2019-nCoV) Originating in China. Cell Host \& Microbe 2020, 27, 325-328, doi:10.1016/j.chom.2020.02.001.

28. Zhang, T.; Wu, Q.; Zhang, Z. Pangolin homology associated with 2019-nCoV; Pathology, 2020;

29. Ruiz-Arrondo, I.; Portillo, A.; Palomar, A.M.; Santibanez, S.; Santibanez, P.; Cervera, C.; Oteo, J.A. Detection of SARS-CoV-2 in pets living with COVID-19 owners diagnosed during the COVID-19 lockdown in Spain: A case of an asymptomatic cat with SARS-CoV-2 in Europe. medRxiv 2020, 2020.05.14.20101444, doi:10.1101/2020.05.14.20101444.

30. Mallapaty, S. What's the risk that animals will spread the coronavirus? Nature 2020, d41586-02001574-4, doi:10.1038/d41586-020-01574-4.

31. Shi, J.; Wen, Z.; Zhong, G.; Yang, H.; Wang, C.; Liu, R.; He, X.; Shuai, L.; Sun, Z.; Zhao, Y.; et al. Susceptibility of ferrets, cats, dogs, and different domestic animals to SARS-coronavirus-2. bioRxiv 2020, 2020.03.30.015347, doi:10.1101/2020.03.30.015347.

32. Oreshkova, N.; Molenaar, R.-J.; Vreman, S.; Harders, F.; Munnink, B.B.O.; Hakze, R.; Gerhards, N.; Tolsma, P.; Bouwstra, R.; Sikkema, R.; et al. SARS-CoV2 infection in farmed mink, Netherlands, April 2020; Microbiology, 2020;

33. Simin, W.; Ge, Y.; Murphy, F. Update: A Hong Kong Dog Tested Positive for Coronavirus, And That's All Anyone Can Agree On - Caixin Global Available online: https://www.caixinglobal.com/202003-05/a-hong-kong-dog-tested-positive-for-coronavirus-and-thats-all-anyone-can-agree-on101524525.html (accessed on Aug 13, 2020). 
34. Enserink, M. Coronavirus rips through Dutch mink farms, triggering culls to prevent human infections Available online: https://www.sciencemag.org/news/2020/06/coronavirus-rips-through-dutchmink-farms-triggering-culls-prevent-human-infections (accessed on Aug 13, 2020).

35. Chini, M. Coronavirus: Belgium reaches 7,284 confirmed cases Available online:

https://www.brusselstimes.com/all-news/belgium-all-news/102984/coronavirus-belgium-reaches-7284confirmed-cases/ (accessed on Aug 13, 2020).

36. Hong Kong's Information Services Department Pet cat tests positive for COVID-19 Available online: http://www.news.gov.hk/eng/2020/03/20200331/20200331_220128_110.html (accessed on Aug $13,2020)$.

37. OIE Information received on 01/03/2020 from Dr Thomas Sit, Chief Veterinary Officer / Assistant Director (Inspection \& Quarantine), Agriculture, Fisheries and Conservation Department, Hong Kong Special Administrative Region Government, Hong Kong , Hong Kong (SAR - PRC) Available online: https://www.oie.int/wahis_2/public/wahid.php/Reviewreport/Review?page_refer=MapFullEventReport\&r eportid=33455 (accessed on Aug 13, 2020).

38. The Free Press Madhya Pradesh: Pench forest staff qurantined after death of corona positive tiger is fit now Available online: https://www.freepressjournal.in/bhopal/madhya-pradesh-pench-forest-staffqurantined-after-death-of-corona-positive-tiger-is-fit-now (accessed on Aug 13, 2020).

39. Newman, A.; Smith, D.; Ghai, R.R.; Wallace, R.M.; Torchetti, M.K.; Loiacono, C.; Murrell, L.S.; Carpenter, A.; Moroff, S.; Rooney, J.A.; et al. First Reported Cases of SARS-CoV-2 Infection in Companion Animals - New York, March-April 2020. MMWR Morb Mortal Wkly Rep 2020, 69, 710713, doi:10.15585/mmwr.mm6923e3.

40. McAloose, D.; Laverack, M.; Wang, L.; Killian, M.L.; Caserta, L.C.; Yuan, F.; Mitchell, P.K.; Queen, K.; Mauldin, M.R.; Cronk, B.D.; et al. From people to Panthera: Natural SARS-CoV-2 infection in tigers and lions at the Bronx Zoo. bioRxiv 2020, 2020.07.22.213959, doi:10.1101/2020.07.22.213959.

41. Promed Post - ProMED-mail 2020.

42. Halfmann, P.J.; Hatta, M.; Chiba, S.; Maemura, T.; Fan, S.; Takeda, M.; Kinoshita, N.; Hattori, S.; Sakai-Tagawa, Y.; Iwatsuki-Horimoto, K.; et al. Transmission of SARS-CoV-2 in Domestic Cats. New England Journal of Medicine 2020, 383, 592-594, doi:10.1056/NEJMc2013400.

43. Volz, A. Coronavirus Disease 2019 Update (181): Germany (Bavaria), France (NouvelleAquitaine), Cat, Oie Animal Case Definition 2020. 
44. AFP, L.F. avec Un deuxième chat testé positif au coronavirus en France Available online: https://www.lefigaro.fr/sciences/un-deuxieme-chat-teste-positif-au-coronavirus-en-france-20200512 (accessed on Aug 13, 2020).

45. Dodds, W.J. Coronavirus SARS-CoV-2 (COVID-19) and Companion Animal Pets. J Immuno Allerg 2020, 1, 1-3.

46. Chai, L.; Xin, H.; Zhao, Y.; Richardson, B. Egg Flats and Pallets Disinfection with Heat Treatment. Animal Industry Report, 2018, 664(1).

47. Zhao, Y.; Chai, L.; Richardson, B.; Xin, H. Field evaluation of an electrostatic air filtration system for reducing incoming particulate matter of a hen house. Transactions of the ASABE 2018, 61, $295-304$.

48. Zhao, Y.; Richardson, B.; Takle, E.; Chai, L.; Schmitt, D.; Xin, H. Airborne transmission may have played a role in the spread of 2015 highly pathogenic avian influenza outbreaks in the United States.

Scientific reports 2019, 9, 1-10. 